\title{
Chernozems of Ukraine: past, present and future perspectives
}

\begin{abstract}
The aim of the paper was to show the significance of chernozems for the Ukrainian economy, science and culture. The spatial distribution as well as variation of features of chernozems in Ukraine (including the uniqueness of these soils) was described. Also a brief history of investigation of Ukrainian chernozems was outlined. Particular emphasis was placed on the problems of degradation and protection of chernozems.
\end{abstract}

Keywords: Chernozems, Ukraine, soil genesis, soil zonality.

\section{INTRODUCTION}

Chernozems are among the most important soils on Earth. The total area of chernozems is about 314 million hectares, which is ca. $2.4 \%$ of the world soil cover. Chernozems form continuous zones on Eurasian and North American continents. Large areas of chernozems can be found in South America, in Argentina and Uruguay as well as in Australia. In Eurasia, chernozems extend from the Vojvodina (Serbia) to the Lake Khanka in China, which is more than 10 thousand $\mathrm{km}$ (Pozniak 2015).

In genetic terms, chernozems are humus, calcium and montmorillonite-rich soils with long, complex pedogenesis that include both the former and modern automorphic-hydromorphic stages of soil development. The significant basis for the formation of chernozems was a positive balance of nutrients and solar energy resulting in: (1) the characteristic profile morphology, (2) abundance of humus with large reserves of nitrogen, phosphorus, potassium, microelements and (3) optimal water-air regime as well as (4) active biological and biochemical processes. Therefore chernozems play important ecological functions, ensuring the functioning of the biosphere. In a certain sense, chernozem sare a phenomena of nature creating a special habitat, a special constitution, have an excellent properties and high fertility (Balyuk and Truskavets'kyy 2015).

Chernozems, with few exceptions, remained untouched for thousands of years, because the steppes were populated bynomadic peoples. Their main occupation was animal breeding, which is characterized with the closed biological cycle in which all the acquired organic material was returned into the soil. In addition, there was continuous accumulation of solar energy, which caused an increase in potential soil fertility. This can be one of the reasons for the phenomenally high bioenergy of chernozems and their stability. From 17 th to 19 th century the settled population started rapid and extensive cultivation of the chernozems (Dokuchaev 1949).

"Chernozem" is a Ukrainian word and has a national meaning. It is often used in everyday life, folklore and even in poems. In the soil nomenclature of various countries and international World Reference Base for Soil Resources (IUSS Working Group WRB 2015), the term is used without a translation.

The aim of this work is to describe the significance of chernozems for Ukraine and for Ukrainian science and culture.

\section{SPREAD AND SPATIAL VARIABILITY OF CHERNOZEMS IN UKRAINE}

Ukraine has one of the largest chernozem territories in the world. In Ukraine, these soils cover almost 27.8 million ha, representing $8.7 \%$ of the world's total chernozem areas and create crucial territory for crop production (Balyuk and Truskavets'kyy 2015). Most cereals, sugar beet, sunflower, perennial fruit, aromatic crops in Ukraine are cultivated on these soils. Chernozems form $67.7 \%$ of agricultural terrain in Ukraine $-67.7 \%$ and have almost completely been converted into arable lands.

Ukraine has a leading place in the World in a land and soil resources availability per person. In 2012, for one inhabitant in Ukraine could be accounted ca.1.32 ha of the land area, 0.92 ha of the agricultural land, 0.71 ha of the arable land and 0.59 ha of cherno- 
zems, while this is only 0.19 ha of the arable land and 0.045 ha of chernozem per person in the world (Table).

There are several types of chernozems in Ukraine (Atlas of soils of the Ukrainian SSR 1979): regular chernozems (10.9 million ha), typical chernozems ( 6.2 million ha) and southern-steppe chernozems (3.2 million ha). Podzolic chernozems and leached (decarboned) chernozems occupy 2.8 and 1.7 million ha respectively. Outside the typical chernozem zone, the saline chernozems, saline-leached chernozems and chernozems developed from sandstones, shales and carbonate rocks, covering an area of about 3 million ha can be found (Pozniak 2008).

Chernozems predominate in the forest-steppe and steppe zones, extending from the western to eastern border of Ukraine. This causes soil formation in two soil-climatic facies: (1) southwestern, or "warm", and (2) central or "temperate" (Balyuk and Truskavets'kyy 2015). Chernozems of the central facies represent a standard series consisting of all subtypes (Atlas of soils of the Ukrainian SSR 1979)from podzolic to southern chernozems. The southwest chernozem facies are "micellar-carbonate" due to occurrence of thin veins that consist of carbonate salts. Recently, some small areas of chernozems occurring in the Small Polissia and Polissia have been found (Pozniak 1997; Papish 2017).

In Ukraine ,chernozems can be found mostly on flatten watersheds as well as on slightly inclined surfaces and on high terraces, both covered by loess and loess-like formations. However, there are small amounts of chernozems developed on non-loess sediments/rocks like leached carbonate rocks and gypsum, etc. (Lebedeva and Ovechkin 1975; Pozniak 2008).

TABLE. Availability of land and Chernozems in selected countries (Balyuk and Truskavets`kyy 2015)

\begin{tabular}{lclll}
\hline Country & \multicolumn{3}{l}{ Hectares per person } \\
\cline { 2 - 5 } & $\begin{array}{l}\text { Total land } \\
\text { area }\end{array}$ & $\begin{array}{l}\text { Agricultural } \\
\text { Lands }\end{array}$ & $\begin{array}{l}\text { Arable } \\
\text { Lands }\end{array}$ & $\begin{array}{l}\text { Cherno- } \\
\text { zems }\end{array}$ \\
\hline Ukraine & 1.32 & 0.92 & 0.71 & 0.59 \\
\hline Poland & 0.82 & 0.49 & 0.37 & 0.01 \\
\hline Germany & 0.44 & 0.21 & 0.14 & 0.01 \\
\hline France & 1.03 & 0.51 & 0.28 & - \\
\hline Great Britain & 0.39 & 0.30 & 0.09 & - \\
\hline Canada & 28.61 & 2.30 & 1.30 & 0.22 \\
\hline USA & 3.04 & 1.45 & 0.56 & 0.18 \\
\hline Russia & 11.95 & 1.46 & 0.87 & 1.02 \\
\hline China & 0.71 & 0.007 & 0.10 & 0.03 \\
\hline Japan & 0.30 & 0.04 & 0.03 & - \\
\hline In the World & 1.86 & 0.66 & 0.19 & 0.045 \\
\hline
\end{tabular}

\section{THE INVESTIGATIOOF CHERNOZEMS IN UKRAINE - A BRIEF HISTORY}

The history of chernozems investigation in Ukraine is one of the forgotten pages in Ukrainian soils science. At the root of the "chernozem doctrine" that was preceded by Dokuchaev were Kharkiv scientists, professors Borisyak and Levakovskiy (Pozniak and Havrysh 2019). Borisyak in his work "The Chernozems" published in 1852 has explained the genesis of chernozems and described their properties and methods of use. 30 years later, in afamous work "Russian Chernozems" published in 1883, Dokuchaev(1949) has described in detail the soils not only in Ukraine, but also in Bessarabia, Volga Delta and Central Chernozem regions. An important contribution to the study of chernozems of Galicia and Podillia was made by Austrian scientist Leonid Buber. In 1910 he published a book entitled "The Chernozems of Galicia and Podolia", which not only presents characteristics of natural conditions and properties of chernozems, but also their commercial use (Pozniak and Havrysh 2019).

In the 20s and 30s of the twentieth century soil and geographical research culminated in compilation of the soil map of Ukraine. Large factual data about properties of chernozems characteristics were summarized in 1930 the manuscript "Soils of Ukraine" of Mahov (Krupenykov 2008).

The large-scale soil surveys and mapping actions conducted in 1957-1961 have a particular importance for Ukraine. The result of these investigations was the data summarization on (1) morphogenetic features of chernozems, (2) their use and (3) on the improvement of its fertility (Atlas of soils of the Ukrainian SSR 1979).

Ukrainian chernozems are still an important subject of the scientific research. It should be emphasised that in the second part of 20thcentury and in the 21 stcentury, many research works were conducted on the genesis of chernozems (e.g. Lebedeva and Ovechkin 1975; Papish 2017), soil biological activity of these soils (e.g. Demyanyuk et al. 2018), dynamics of the soil organic matter (e.g. Mamontov 1975; Kravchenko et al. 2012; Demydenko and Velychko 2015) and transformation of the soils due to agricultural activity (Gninenko and Kizyakov 1983; Poznyak 1990; Filon 1996; Demyanyuk et al. 2018).

\section{THE UNIQUENESS OF UKRAINIAN CHERNOZEMS PROPERTIES}

In chernozems, various processes occur continuously. These include the transformation of substances, their migration, degradation, dissolution and accumu- 
lation. The combination of these and many other processes is called the chernozem physiology. These processes are cyclic, repeated day after day, year after year and form the rhythm of life of these soils. Chernozems have spectacular profiles, the horizons are genetically closely related and there are no sharp transitions between them. The dark humus horizon of Ukrainian chernozem can reach up to $220 \mathrm{~cm}$, which makes this soil unique in this respect.

Chernozems are like living organisms. It is a combination of the long root systems that can reach depths of $120-140 \mathrm{~cm}$ and active vertebrate and invertebrate organisms that transform crop residues, causing biogenic emissions and their typical structure. In one gram of a chernozem, about 3.5 million of living organisms can be found, while there are 55 million organisms in one gram of humic material from this soil. Because of this, chernozems are called the miracle of the biosphere. Usually, there is no more than $0.5 \%$ of the actual living matter and less than $10 \%$ of soil organic matter (humus) in topsoil of chernozem. The mineral mass of soil has been processed by living organisms over thousands of years and the combination of living and non-living parts gives us reason to call these soils "the fourth kingdom of nature" and the crown of the kingdom is chernozems.

Chernozems have optimum soil organic matter (humus) content - its quantity and quality as well as its profile distribution. The content of humus in chernozems ranges from 3 to $10 \%$ (or even more). An estimated reserves of humus in chernozems in Ukraine ranges between192-247 tonnes/ha in the southern chernozems, 260-533 t/ha in the regular, 260-560 t/ha in typical and 200-410 t/ha in podzolic chernozems (Demydenko andVelychko 2015).

The composition of humus in chernozems is dominated by black humic acids, especially important for the soil fertility and the lighter and more soluble fulvic acids. These organic acids linked mostly with calcium, which gives them stability and large exchange capacity. The humus is distributed evenly across the topsoil, gradually decreasing and reaching depths of $60 ? 80 \mathrm{~cm}$ in the southern chernozems and 150-170 $\mathrm{cm}$ in typical chernozems of Dnipro Right-Bank Forest-Steppe.

Chernozems are characterized with high cation exchange capacity (30-70 mg/100 g of soils), high base saturation, neutral reaction, high buffer capacity, favourable physical properties caused by crumb structure and texture (usually inherited from parent material) and optimal bulk density $\left(1.0-1.2 \mathrm{~g} / \mathrm{cm}^{3}\right)$, porosity, humidity, water permeability ( $200 \mathrm{~mm} /$ year) and pools of macro (N, P, K, Ca, Mg, S) and microelements. Chernozems, by their nature, have a neutral reaction throughout the profile and only the alkalized and podzolic chernozems may have a slightly acidic reaction.

Chernozems are quite old soils as they began to form about10 thousand years ago (Kravchenko et al 2012). During a long period, these soils became a huge reservoir of concentrated solar energy. The accumulation of potential chemical energy is up to 3.4 billion calories per 1 ha. It playsa role as the basis of high biological productivity of chernozems, their resistance to changes and the ability to ensure the performance of photosynthesis of plants. These features contribute to exceptional natural values of chernozems in agriculture world and in Ukraine in particular.

Due to their properties, chernozems have high fertility for a variety of crops. The total grain harvest in Ukraine in 2015 was almost 61.1 million tons and the average yield is $4.2 \mathrm{t} / \mathrm{ha}$. In some agriculture companies of Cherkaska and Poltavska Oblast, the wheat yield was 11.6-13.8 t/ha (Balyuk and Truskavets'kyy 2015).

From an aesthetic point of view, chernozem is just a beautiful soil, due to its purely black colour in a virgin state, and structural edges on the ploughed furrow crests reminiscent of raven wings. In the spring, the ploughing chernozem is raised in haze, then falls, trembling in the spring, breathes and smells as the living black earth. All these form the aesthetic grandeur of chernozems and there fertility potential.

\section{DEGRADATION AND PROTECTION OF CHERNOZEMS IN UKRAINE}

In the 20th century, in particular during the era of technical progress and globalization, the contemptuous behaviour towards chernozems has significantly increased. Moreover, analysis of many annual reports of the nature protection organizations shows no interest in these soils as a conservation subject; on the contrary, chernozems are still in the process of rapid degradation (Krupenykov 2008).

Plowing and long cultivation may lead to a gradual degradation of chernozems. The area of ploughed chernozems in Ukrainian Forest-Steppe zone reaches $85 \%$ and $90 \%$ in the Steppe zone. Although this area has decreased slightly in recent years, it still remains high as compared to the general contribution of the plowed soil in Ukraine, which is ca. 54\% of the land territory.

The predominant factor of erosion is water and wind, but the intensive ploughing causes the intensification of erosion process. In general, eroded arable land constitutes $30 \%$ of all the arable land, while in the chernozem area it is ca. $25 \%$ (among them: $18 \%$ 
slightly eroded, 5\% moderately eroded and 2\% strongly eroded). Erosion is a kind of guillotine for chernozems, causing loss of the habitat, decreasing humus content, degradation and general reduction of its fertility. Intensive deterioration of the soil structure causes the formation of large soil clods. Also erosion caused irreparable damage to the environment and lead significant negative environmental effects. In Ukraine, 130 years after the research of Dokuchaev, the average annual loss of humus in chernozem topsoil horizons ranges from 21 to $40 \%$, i.e. $0.5-0.9$ t/ha (Kravchenko et al. 2012). For example, the humus content in the upper $30 \mathrm{~cm}$ depth of chernozems in Sumy Reserves "Myhailivska Tsilyna" is $9.5-10 \%$, and in the same chernozems, but arable, the humus content is $4.5-5 \%$ (Mamontov 1975).

During erosion, chernozems lose chemically bound energy, aggregation and porosity, which are important for the preservation of their fertility. It was estimated that over the past 40 years, chernozems have absorbed enough energy to boil the Black Sea. The famous Ukrainian philosopher Mykola Rudenkoin work "Energy Progress" explained the opinion that "the wealth of the nation is not in money but in the products of agriculture" and the economy generator is farming and wheat production (Rudenko 2015).

Considerable changes took place in chernozems due to the intensification of agrotechnogenic impact during the last 40 years. Due to extensive agricultural production in the first period after conversion, soil fertility is characterized by a gradual degradation. In typical chernozems, the humus content has decreased by $21-38 \%$, absorbed calcium $26-37 \%$, waterproof aggregates (more than $0.25 \mathrm{~mm}$ ) $33 \%$ and mineral nitrogen, soluble phosphates and metabolic potassium $34-40,39-40$ and $22-24 \%$ respectively (Makhov 1930).

In the recent years, high technologies oriented on yield maximization have been implemented on large areas for growing of the market-oriented varieties of winter wheat, corn, sunflower and winter rape. However, the nutrients, especially nitrogen, are not balanced and a large portion of nutrients is consumed from the inner stock of chernozems (Filon 1996; Demyanyuk et al. 2018). Also irrigation of chernozems in Ukraine is one of the powerful factors of human intervention within Steppe zone. If ploughing and fertilization affects mainly on the uppermost soil horizons, the irrigation may effect on the whole soil profile and even deeper. Under the influence of irrigation, the water, salt, thermal, microbiological, gas and nutrient regimes in chernozems have been altered and the new processes not particular for these soils have occurred, like rising ground-water levels, flooding, salinization, alkalinization, removal of nutrients (including calcium), deterioration of physical properties, formation of a hard layer on the surface and fracturing etc. (Poznyak 1990; Pozniak 1997). Over the past decade, the area of irrigated land has considerably decreased and actuallyincludes600-700 thousand hectares (Nosko 2006).

Considerable damage of chernozems is caused by the local waterlogging, alkalinisation, pollution by industrial and communal wastes as well as the contamination with heavy metals (Krupenykov 2008). Irreparable damage to chernozems occurred in open mining process and road construction, industrial activity and other interference. There are cases of transfer of chernozems into unsuitable for agricultural production lands based on decisions of local administration, especially near large cities, as well as individual cases of soil sale "for export" (Nosko 2006).

A new problem has arisen over the past years - the military degradation of chernozems in Donbas region. In the areas of military operations, the destruction of highly productive soils increased, which leads to disruption of the morphological structure of the profile, mixing of the genetic horizons (due to bursting of mines, grenades, construction of trenches, dugouts, etc., the formation of large areas of craters, trenches, pits etc.), changing the composition and soil properties, unusual occurrence in soil inclusions (e.g. metals from weapon and ammunition) and intensive compaction caused by heavy machinery, etc. (Pozniak 2008).

Violation of the soil and soil cover caused by military degradation needs to conduct the soil-geographic studies and modern soil mapping on Donbas area, to study the properties of disturbed soils and their agro-ecological evaluation. It is necessary to carry out the soil remediation in order to return it to the normal use. Solving this problem will be a very important step in the revival of Donbass region.

In conclusion, we can state that degradation of chernozems in Ukraine has not yet turned into a disaster (except in areas of military conflict). The state should develop and implement the legal acts for soil protection, organization of soil monitoring, changing of the land use system and for the land use control. The scientists have developed the country-scale programs for effective soil use and improvement of the fertility of soils, including chernozems, which are discussed at different levels, but are still not accepted officially, and therefore state funds are not allocated for their implementation (Balyuk and Truskavets'kyy 2015; Pozniak and Havrysh 2019).

Chernozem is the ideal standard of excellence among the world soils. In many countries, soils were artificially transformed and improved to create soils 
similar in their fertility to chernozems to achieve the food independence (the so-called culturozems). In several countries, i.e. Germany and Austria (2005), Estonia (2015) and Poland (2019)chernozem was declared the "Soil of the Year" (Altermann et al. 2005; Kõlli and Tamm 2015; Kabała 2019). On this occasion, Austrian post has issued a stamp with the image of chernozem. In Ukraine, these soils are still kept in a virgin state in some places, as in the Nature Reserves "Myhailivskatsilyna" Sumy Oblast, "Homutivskyy Step" Donetsk Oblast, "Striltsivskyi Step" Lugansk Oblast and "Kamiani Mogyly" Zaporizhia Oblast, and in Nature Reserve Site "Kasova Gora" Ivano-Frankivsk Oblast.

\section{CONCLUSION}

Chernozem is of huge importance in nature, agriculture and social life due to its uniqueness properties, fertility and aesthetic values. Several scientific monographs, works of art, poetry and monuments are dedicated to chernozems. The collection of chernozem monoliths may be seen in many world museums and educational institutions. Chernozem is the world heritage, the basement for agriculture on the Earth, so its preservation and augmentation of its power is an important task and duty of all mankind.

In a broad sense, the well-being of Ukraine is largely based on the benefits from chernozem, the eternal breadwinner. It is no coincidence that the chernozems from the area Dobrovelychkivka (Kirovohrad Oblast) are exhibited in the International Soil Reference and Wageningen University and Research Center as a "standard Chernozem".

\section{REFERENCES}

Altermann M., Rinklebe J., Merbach I., Körschens M., Langer U., Hofmann B., 2005. Chernozem - soil of the year 2005. Journal of Plant Nutrition and Soil Science 168(6): 725-740.

Atlas of soils of the Ukrainian SSR, 1979. Kyiv: 145 (in Russian).

Balyuk S.A., Truskavets'kyy R.S., 2015. System management transformational orientation of soil's fertility. Collection of Works: Genesis, geography and ecology of soils.L'viv: 5-12 (in Ukrainian).

Demyanyuk O.S., Sherstoboeva O.V., Bunas A.A., Dmitrenko O.V., 2018. Effects of different fertilizer systems and hydrothermal factors on microbial activity in the chernozem in Ukraine. Biosystems Diversity 26(4): 309-315.

Demydenko O.V., Velychko V.A., 2015. Humus state of chernozem at different ways of tillage in the agrosystems of the left-bank forest steppe of Ukraine. Agricultural Science and Practice 2(3): 61-76.
Dokuchaev V.V., 1949. Russian chernozem. [In:] Works. T. 3. Publishing house of the USSR Academy of Sciences, Leningrad: 624 pp. (in Russian).

Filon I.I., 1996. The effects of long-term use of fertilizers on the mineral composition of typical chernozems of the foreststeppe region in the left-bank part of the Ukraine. Eurasian Soil Science 28(8): 53-60.

Gninenko N.V., Kizyakov Y.Y., 1983. Variations in the compaction of ordinary chernozems under major field crops in the steppe zone of the Ukraine. Soviet Soil Science 15(2): 111-117.

IUSS Working Group WRB, 2015. World Reference Base for Soil Resources 2014, update 2015. International soil classification system for naming soils and creating legends for soil maps. World Soil Resources Reports, 106. FAO, Rome: 192 pp.

Kabała C., 2019. Chernozem (czarnoziem) - Soil of the Year 2019 in Poland. Origin, classification and use of chernozems in Poland. Soil Science Annual 70(2): 71-97.

Kõlli R., Tamm I., 2015. Soil on limestone-year 2015 soil of Estonia. Agraarteadus 26(2): 51-61.

Kravchenko Y., Rogovska N., Petrenko L., Zhang X., Song C., Chen Y., 2012. Quality and dynamics of soil organic matter in a typical Chernozem of Ukraine under different long-term tillage systems. Canadian Journal of Soil Science 92(3): 429438.

Krupenykov I.A., 2008. Chernozems. Appearance, perfection, tragedy degradation, path of protection and renaissance. Pontos, Kishineu: 288 pp. (in Russian).

Lebedeva I.I., Ovechkin S.V., 1975. New carbonate formations in chernozems of Ukraine east of Dnieper. Soviet Soil Science 7(6): 637-653.

Makhov G.G., 1930. Soils of Ukraine.Radyans?kyypys?mennyk. Kyiv: 330 pp. (in Ukrainian).

Mamontov V.T., 1975. Change in content of humus and in its qualitative composition under effect of agricultural use of thick chernozem in western forest steppe of Ukraine. Soviet Soil Science 7(2): 173-181.

Nosko B S., 2006. Anthropogenic evolution of Chernozems. NSC ISSAR, Kharkiv: 240 pp. (in Ukrainian).

Papish I., 2017. Differentiation of the material composition of Lviv region LuvicGreyzemic Chernozems (Ukraine). Polish Journal of Soil Science 50(1): 11-20.

Pozniak S., 2008. Chernozems. [In:] Environmental Encyclopaedia (Tolstoukhov A.V., Editor). Centre for Environmental Education and Information. Kyiv: 368-369 (in Ukrainian).

Pozniak S.P., 1997. Irrigated chernozems of South-Western Ukraine. VNTL Publ., Lvov: 125 pp. (in Russian).

Pozniak S.P., 2015. Soils in modern changing world. [In:] Collection of Works: Genesis, geography and ecology of soils.L'viv: 202-206 (in Ukrainian).

Pozniak S.P., Havrysh N.S., 2019. Soils in the memory of world nations. Polish Journal of Soil Science 52(1): 13-22.

Poznyak S., 1990. Physical-properties of irrigated chernozems of the Southern Ukraine. Soviet Soil Science 22(4): 67-74.

Rudenko M., 2015. Energy of progress. Kyiv: 132-146 (in Ukrainian).

Received: April 4, 2019

Accepted: October 8, 2019

Associated editor: C. Kabata 